\title{
Artist Graduates: Are they Ready to do Business?
}

\section{Dr Angela Wright ${ }^{\mathrm{a}}$}

${ }^{a}$ Department, of Organisation and Professional Development, School of Business, CIT, Cork, Ireland.

\begin{abstract}
Businesses must expose their products and services to customers so as to make sales and be heard. The world of the artist ${ }^{l}$ is no different, and, in the words of the late Luciano Pavarotti, the artist must 'be heard and be seen'. The aim of this paper is to examine if there is a need to ensure that our artistic graduates are 'market ready'. The paper specifically examines this concept in the context of an Irish Institute of Technology (IT). Artists generally do not view the world in terms of business \& commerce, only as a creative space. This research study investigates if there is a need for a special purpose award that would allow already qualified or working artists who have missed out on business education to take business modules at any stage in their careers. The findings in this study are rich and the attitudes to the business world by participating artists are interesting. Having established that artists need some business education, this paper then proceeds to outline what may be needed now, and in the future.
\end{abstract}

Keywords: Artist; Musician; Business Education; Business World.

\footnotetext{
${ }^{1}$ For the purpose of this paper, the term 'artist' is deemed to refer to both performing and visual artists.
} 


\section{Introduction}

Artists are creative and generally do not view the world in terms of business \& commerce. Their brain activity is right-hand sided, which is perfect for creativity, but not for commercial activity. With the exception of one IT in Ireland, artistic students are not catered for in terms of business programmes or business subjects for creative students. This paper will examine if there is an appetite among musicians and artists already operating in the field to study some business modules later in their careers if a special purpose award were made available; for example, a certificate in business for the creative arts. Special purpose awards (SPA) meet specific, relatively narrowly focused, legislative, regulatory, economic, social or personal learning requirements. A SPA would afford the artist a new opportunity to up-skill. The focus of this research therefore, is specifically on artists who are currently 'working artists' and not on existing artistic students and to examine this concept in their specific context.

\section{Background \& research context}

The nature and content of courses need to be determined by the 'needs and wants' of those who are leaving the educational system at any particular point in time (Carter, 2010). In this context, does the working artist have the knowledge to work and operate in the wider world of commerce? This sets the context for this research. There is a lack of structure for involving the student's voice in decision-making in relation to creative arts courses (HEA, 2013). Dramatic changes which have been taking place in higher education and the consequential disruption to the "traditional identities of place, of time, scholarly and student communities" is changing the structure and functions of third level education (O'Connor, 2006). The genesis of this research is founded in the fact that it is now incumbent upon us as educators to be ready to adapt and change to students needs. The aim of this research is to investigate whether an additional award would benefit 'artistic graduates' (those who previously engaged in psychomotor taxonomy ${ }^{2}$ of learning) for their future careers. Thall (2002) is adamant that all artists need a working knowledge of law, for example. For every engagement, a business contract is drawn which must be read, understood and signed. If an appetite is found for this proposed certificate for artists, it is anticipated that, in addressing the educational aim \& learning outcomes, students will have an opportunity to acquire relevant business acumen.

\footnotetext{
${ }^{2}$ E.G:Dave's (1970) and Ferris \& Aziz's (2005) adaptation of Bloom's original Taxonomy. The key categories in this competence capture the development in learning from initial exposure to final unconscious mastery (O’Neill \& Murphy, 2010).
} 


\section{Challenges for creative students}

Artistic and creative people face unique business challenges and they do not view the world from a business perspective. Creative people are 'divergent thinkers' and jump from one thing to the next. Students of creative programmes are unleashed into the world as brilliant performers, artists, dancers, but rarely, if ever, possess any experience of what the competitive marketplace holds for them. The reality is that, to survive, they will have to earn a living in some way. Business students on the other hand, if successful, may also have the benefit of a work placement initially, and find themselves working in a business environment, where they are given clear direction as to what is needed. For the solo artist on the other hand, the problem is just that-'solo'. These gifted creative people are 'on their own' to make business decisions about their futures. My heroes are the ones who survived doing it wrong, who made mistakes, but recovered from them, [(Bono, U.2) in Lawton, Harrington, Cunningham, 2008]. For the purposes of this specific piece of research, is was decided to narrow the focus, and only working musicians (+part-time teaching), performing artists, and art painters whose occupation comes solely from art were chosen to participate in this study. Artists with other revenue streams were not chosen to participate. This research therefore investigates if there is a void in the education of artistic students?

\section{Methodology}

Drawing from the Interpretivist approach, a post-positivistic qualitative method was applied in this research study, as the researcher wanted to extract a rich meaningful depth of data from participants. Qualitative approaches have their philosophical origins in phenomenology (Burnell \& Morgan, 1979), \& a phenomenologist believes that the world \& reality are constructed socially where meaning is found from people (Easterby-Smith et al., 2015). The researcher wanted to delve into the feelings and attitudes towards the research topic. An initial pilot study was conducted to establish if there was an appetite for business knowledge among established artists. Following the positive indications from these initial research findings, full in-depth interviews were then undertaken with a further 11 artists. Theorists [Baker, 2012; Easterby-Smith, 2015; Malhorta, 2015; Saunders et al., 2012] outline that a relatively few number of participants are needed for qualitative in-depth interviewing, (between six and a dozen); therefore, in line with such theorists 11 interviews were completed. The approach adopted in the selection of the number of interview participants was based on 'theoretical sampling', where the number of cases studied is relatively unimportant as outlined by (Glaser \& Strauss, 1967). The researcher had the benefit of having access to these artists directly. Ten interview questions were posed to 11 participants. A semi-structured interview guide was used for the face to face interview 
element, and the findings were analysed using grounded theory, developed by Glaser \& Strauss (1967), thus enabling the researcher to extract meaningful data. In grounded theory, the researcher begins with the transcript from the interview and sifts through the data to group and categorise it. Participants included visual and graphic artists, keyboard players, string players, composers, conductors, and singers. The pool consisted of part-time performers (supplemented their income teaching their instrument) and full-time artists and musicians, with both a national and international profile. To triangulate the data, ensuring reliability \& validity, one focus group with a further 6 artists drawn from a different pool was undertaken to tease out ideas arising from the interviewee process.

\section{Literature}

\subsection{The Artist}

An artist can be defined as a person who produces works in any of the arts that are primarily subject to aesthetic criteria, a person who practices one of the fine arts, especially a painter or sculptor, a person whose trade or profession requires a knowledge of design, drawing, painting, etc., a commercial artist, a person who works in performing arts, as an actor, musician, or singer; a public performer - a mime artist; an artist of dance, $a$ person whose work exhibits exceptional skill, (Dictionary.com). The oxford dictionary defines an artist as the various branches of creative activity, such as painting, music, literature, and dance, (Oxforddictionaries.com).

The question of what is art has long occupied theorists and philosophers, but the issue of who or what is an artist is no less vexing (Grant, 2010). The artist defines art, and it seems increasingly true that nowadays artists also define who and what they are. Definitions by nature are confining and restrictive, while art and its makers seek to be expansive and inclusive: It may be simpler to state what makes an artist a professional than what defines an artist (Grant, 2010). 'Artist' has become a universal statement of creativity or, someone who does something well. Socially, artists are often defined by the positive (freedomloving, convention-defying) or negative (egotistical, bohemian) characteristics that other people attribute to them. Part of an artist's job is to understand how artists are seen and what is expected of them, whether that be a certification committee that wants to see the art, a funding source that wants to read an artist's proposal, or the government that wants to see receipts (Grant, 2010). According to the HEA (2013), in the creative arts in Dublin, for example, what is problematic in terms of defining art is where there is a level of innate prioritisation and separation in the system between the perceived 'fine arts' and applied arts and crafts. "Under contemporary and inclusive definitions of the arts, the high and low arts should not be viewed as opposites or even as a continuum, but rather as a transformation of contemporary practice", (HEA, 2013:44). 
Grant (2010), outlines that in the US, the Internal Revenue Service (IRS) ${ }^{3}$ takes a narrow view of what or who can be defined as a professional artist. Specifically, in relation to individual taxpayer's returns, nine criteria are applied by the IRS in order to separate professionals from hobbyists (professionals may deduct their expenses, hobbyists may not). Some of the criteria for example includes - is the activity carried on in a businesslike manner, does the artist intend to make the artistic activity profitable?, does the individual depend in full or in part from income generated by the artistic work?, are business losses to be expected, or are they due to circumstances beyond the artist's control?, does the activity generate a profit in some years and, if so, how much of one?, will the artist make a profit in the future?, Does the artist have the knowledge to make the activity profitable?, (Grant, 2010). Ironically, Thall (2002) purports that it is widely accepted that really creative people will not know or understand their business. After all, "aren't they living in the realm of the idea - the eigenvelt - the world that is interesting precisely because it is not the mitvelt - the shared world, the concrete, tangible world that can be objectively evaluated?" (Thall, 2002:x). Grant (2010) states that the artist need not answer 'yes' to every IRS question in order to legitimately deduct business related expenses. The IRS demands proof, however, that an artist makes a genuine effort to earn a profit in three years out of a fiveyear span. Artistic credentials may help an artist make a case that he or she is a professional for tax purposes, including earning a bachelor's or Master's degree in fine arts, membership in an artists' society, inclusion in Who's Who in American Art or some similar directory (Grant, 2010).

A knowledge of business in vital (Thall, 2002), and corporations, for example, know that, in order to make sales, they have to expose their products to consumers over and over again. They 'brand' their names into the minds of buyers, so that their products are easily recognized and most likely to be purchased. Through mass advertising on television, newspapers, billboards, etc., big businesses continually drum their identities into ones head; "Ford, Ford, Ford; Pepsi, Pepsi, Pepsi; McDonald's, McDonald's, McDonald's" - Art is no different, (artbusiness.com). In the new environment of technological advance, with the need for the artistic community to adjust to the manifold changes occurring both in the creation and delivery, there is more reason that ever before to examine the industry so that we can better fine-tune our business relationship (Thall, 2002:x). Grant (2010) concurs that artist must have business knowledge, which is confirmed in the IRS statement of what an artist is (IRS.gov) to make the activity profitable and be defined for law enforcement. The best formalised arts education should prepare the student, appropriately, for a career in the creative and/or entrepreneurial world (HEA, 2013). Irish higher education should equip students with the skills to play a strong part on the world stage. This is not just in terms of

\footnotetext{
${ }^{3}$ The IRS is the U.S. government agency responsible for tax collection and tax law enforcement (IRS.gov).
} 
quality and reputation, but as a strategy for innovation that builds a robust future for the Irish society (HEA, 2013).

\section{Research findings}

The findings of this study are very interesting. Artists really do not understand the world of business and in the words of one contributor, "the world is consumed with numbers and trying to make profits. Art is not about that it is about creativity. Their rules don't apply! Business men fail to see the non-monetary and immeasurable benefits of music and arts". The reality of course, is that all musicians and artists must make a living and eat. Survival and a need to pay the bills was the main theme that emerged from the focus groups, but the majority, with the exception of 2 contributors, had no idea of how to apply business skills to their own business - either being a musician, or a visual artist. Of the 11 interviewees, 4 had masters' qualifications in their specific artistic field, (performance/ visual art), 4 had relevant degrees, and 3 had no qualifications in their artistic endeavours. 100\% (all) of participants viewed themselves as 'artists' even though, as one stated, "I am a musician but an entrepreneurial description is more realistic, but I can't see myself in that light at all!". We were never thought to be business people, only top performers, this is where the pressure was applied". Another artist outlined that "you had to fight to be the best artist that you could be. The idea of how we would sell our paintings was never to the fore in college". Another participant stated that, "we only worried about coming out on top of our class and getting noticed!" Another interviewee said, "I burned my fingers off of me trying to be the best in my field. This was my only focus".

This current research has found that artists find themselves "at sea" when faced with the challenging business world. All participants agree and believe that there was a gap or void in their education due to the lack of business knowledge and experience. One participant outlined that "it would have been great to have had financial planning advice in college". $82 \%$ cited knowledge of marketing as an issue, while $100 \%$ of contributors stated that legal issues and contracts were challenging. $90 \%$ of participants relayed that they needed marketing and online training to access markets. "On the go learning" is the only way that I can manage". Social and new media are also mentioned by participants, and one surmised that they had "spend years practicing the piano keyboard, and now half of the time as a musician is spent on the computer keyboard"- "how ironic is that?".

One contributor stated that, in Europe, musicians are "more into their art and themselves, whereas in the US they tend to hustle much more and are not afraid to promote and put themselves out there". Another contributor described that the international arena is a difficult one, especially, in the United States. "I write movie scores, and I have to be in the US market for this". "In the states, you must have all of your paper work in order or you 
would not be allowed entry into the states". Another participant concurred and outlined that "Visa applications are a mine field". They are very difficult and all paper work and taxes must be in order" - and don't start me on the dual taxation issues". Mirroring Grant (2010), the participant went on to outline that if "your tax returns are not in order for example, you will lose your visa and that is it! We are routinely audited by IRS and this incurs serious costs and the need for many personnel. The only way that we can handle this is to have a full time business manager, accountant, \& attorney". The risk and stakes are too high for us otherwise. After a few mistakes you learn fast, but it would have been a great help if I had some initial business understanding". "My business partners (that's funny/artistic partners) always say the same thing". "When we went into the international arena we had to set up two new corporations to handle all of the various aspects of the business". The findings of this research indicate that the Irish as a nation are shy, and need the benefit and confidence that comes from formal training - in this case, business training. All contributors agreed that there is a definite need to study business subjects. The findings of the focus group session echoed the sentiments of the interviewees in terms of educational gaps, and it also proved very beneficial in discussing the modules and subjects that would be beneficial for artists in the future, such as ;Law , Accounting, Marketing, website design, PR, \& Entrepreneurial skills for business start ups. Having established that a need exists for business learning and education for artists, the next step is to consider the specific findings.

\section{Recommendations}

There is a need to provide business education for new entry artistic students in Higher Education by integrating business modules into their existing courses. This can be achieved by offering already approved business subjects as electives initially, with a view to introducing them as compulsory elements later.

For already working artists who are out of the educational system, a need exists to develop a Special Purpose Award (SPA) for artists who have no business education. For a SPA to be successful learner access must be considered and, according to the HEA (2013), the Irish higher education system must continue to develop clear routes of progression and transfer, as well as non-traditional entry routes.

For proper integration, for learners graduating from a BMus, for example, it is recommended that these learners may progress onto the special purpose award, but will need to attend a short introductory business induction course for 1 week as this field of study is completely new.

For a 'stand-alone' artist or artists that have been out of education for a long period of time, or, indeed, those who have never attended a third level institution, it will be necessary and 
recommended to partake in a longer bridging/transitional course that would include writing skills, an introduction to business subjects, computer skills etc.

Higher education alone cannot be held accountable for all creative and cultural learning. There needs to be complementarity and consistency in the approach to curriculum design and delivery (HEA, 2013). This study specifically considered already working artists and solutions for them to fill the void in their education; however, other short-term solutions could be considered such as running non-accredited courses to up-skill for such artists. Such workshops could coincide with some of the major festivals operating throughout the year, and research could be undertaken to see if opportunities could arise to acquire some funding for same from the arts council, for example, [http://www.artscouncil.ie/availablefunding/]. This could prove to be challenging, however, given the current economic climate and also the competitive nature of such funding.

Funding avenues could and should be identified and explored. The HEA outline that the success of research funding in the creative arts is largely judged on the quality of the outcomes and impact of that research.

\section{Conclusion}

For many artistic graduates, learning business skills 'on the job' is now the norm. Higher Education Institutions in Ireland (with one exception) need to address this educational gap for its new undergraduate intake for the creative arts in the future.

A new programme, a SPA award in line with the QQI (Quality \& Qualifications Ireland) Level 6 Certificate (qqi.ie) should be developed for former graduates who have missed out on any business education to date, and also for other creative working artists who have no business education or knowledge. This new programme fill a void in the education of our creative students. The objective will be that the student will achieve practical knowledge of business in the future. Other educational opportunities should be examined in the form of short-term courses for working creative artists. The benefit of these short courses is that they would 'ease' the artist back into the educational system.

As an immediate imperative, an internal review of specific academic offerings within the institutions is needed in order to inform a coherent and inter-related system that is conducive to optimal quality, efficiency and a type of critical mass better suited to a connected and creative milieu (HEA, 2013). Thoughtful consideration must be given to the implementation of business education in the future planning strategies by management in Higher Education in Ireland. 


\section{References}

ArtBusiness.com. Available at http://www.artbusiness.com/maxprice.html, accessed May 2, 2015 at $6 \mathrm{pm}$.

Baker, S.E. (2012). "How many qualitative interviews is enough?", National Centre for Research Methods Review Paper, University of Southampton: NCRM, available at http://eprints.ncrm.ac.uk/2273/4/how_many_interviews.pdf, accessed May 6, 2015 at $10 \mathrm{pm}$.

Burnell, G., Morgan, G. (1979). Sociological Paradigms and Organisational Analysis, Elements of the Sociology of Corporate Life, London:Heinemann.

Carter, R. (2010) "A Taxonomy of Objectives for Professional Education", Studies in Higher Education, Vol. 10, No. 2. 1985, online 2010.

Easterby-Smith, M., Thorpe, R., Jackson, P.R. (2015). Management \& Business Research, UK:Sage.

Glaser, B.G \& Strauss, A.L., (1967). The Discovery of Grounded Theory: Strategies for Qualitative Research, Chicago: Aldine Publishing Company.

Grant, D. (2010). "How do you define 'Artist'? Huffington Post, available at http://www.huffingtonpost.com/daniel-grant/how-do-you-define-artist b 582329.html, accessed May 8, 2015 at 7.30pm.

Hea.ie. (2013). "Review of the Provision of Creative Arts Programmes in Dublin", Higher Education Authority, Ireland, available at http://www.hea.ie/sites/default/files/dublin_creative_arts_review_0.pdf 6th February 2015 , accessed, August $17^{\text {th }}, 2015$ at $6 \mathrm{pm}$.

http://www.artscouncil.ie/available-funding/, Irish Arts Council, accessed August $17^{\text {th }}$, 2015, at 4pm.

IRS.gov. Internal Revenue Service, available at http://www.irs.gov/, accessed May $17^{\text {th }}$ at $6 \mathrm{pm}$.

Knight, P. (2001). A Briefing on Key Concepts Formative and summative, criterion \& norm-referenced, Assessment Series no. 7 / LTSN Generic Assessment Centre, available at http://resourcelists.coventry.ac.uk/items/FC069ECC-917B-0C6D-5F415FD8B0B56800.html, accessed, April 10 ${ }^{\text {th }}, 2016,1 \mathrm{pm}$.

Malhorta, N.K. (2015). Essentials of Marketing Research, US: Prentice Hall.

O’Connor, C. (2006). "Designing curriculum and assessment to promote effective learning in chemistry in higher education", available at, http://level3.dit.ie/html/issue4/christine_oconnor_paper_2/oconnor2.pdf,accessed

November 1, 2015 at $10 \mathrm{pm}$.

O’Neill, G., and Murphy, F. (2010). Guide to Taxonomies of Learning, Dublin: UCD. TEACHING AND LEARNING/ RESOURCES, at http://www.ucd.ie/t4cms/ucdtla0034.pdf, accessed November 1, 2015 at 10pm.

Oxforddictionaries.com. Available at http://www.oxforddictionaries.com/definition/english/art, accessed May 7, 2015 at 7pm.

QQI.ie. available at http://www.qqi.ie/Pages/default.aspx, accessed November $5^{\text {th }} 2015$ at $9 \mathrm{pm}$. 
Roberts, P. (2011). "New perspectives shaping the Higher Education Curriculum as a space for learning", (0232), available at http://www.srhe.ac.uk/conference2011/abstracts/0232.pdf, accessed November 2, 2015, at $11 \mathrm{am}$.

Saunders, M., Lewis, P., Thornhill, A. (2012). Research Methods for Business Students, UK:Pearson.

Thall, P.M. (2002). What they'll never tell you about the music Business, the Myths, the secrets, the lies (\& a few truths), Watson-Guptill:NewYork. 